\title{
NACRT EKOLOŠKE DUHOVNOSTI PREMA ENCIKLICI LAUDATO Sİ PAPE FRANJE
}

\author{
Mladen Parlov
}

Sveučilište u Splitu

UDK: 159.947.23:502.172]272.732.2Franciscus, papa

Katolički bogoslovni fakultet

mladenparlov@gmail.com

Prethodno priopćenje

Rad zaprimljen 3/2019.

\section{Sažetak}

Na tragu enciklike pape Franje Laudato sì, koja govori o brizi za Zemlju kao zajednički dom svih ljudi, autor nudi nacrt ekološke duhounosti. Početak ispravne ekološke duhounosti je ekološko obraćenje, koje nije drugo doli obnovljena svijest kako se iz naše vjere $i$ susreta s Isusom Kristom treba mijenjati i naš odnos prema svijetu koji nas okružuje. Ekološko obraćenje treba pomoći vjernicima da iznova i na ispravan način razviju svijest o vlastitoj stvorenosti, o vlastitoj uronjenosti u svijet stvorenja s kojima su međusobno povezani. Ispravan ekološki stav dovest će do nutarnje ravnoteže u samom čovjeku, do solidarne ravnoteže s drugima, do prirodne ravnoteže sa svim živim bićima te do duhovne ravnoteže s Bogom. Ekološka svijest može pomoći ne samo očuvanju okoliša, što se nameće kao jedan od temeljnih ciljeva, nego i do promjene ponašanja koja može podići kvalitetu življenja, kako pojedinca tako i obitelji. Ekološka duhovnost na nov način shvaća i živi sakramente, kao sredstva spasenja i posvećenja, budući da se u sakramentima Bog služi vidljivom materijom kako bi priopćio svoju (nevidljivu) milost. Ekoduhovnost poziva na odgoj $i$ usvajanje novih stavova u životu suvremenih kršćana, koji im trebaju pomoći na ispravan način odnositi se prema stvorenom svijetu.

Ključne riječi: papa Franjo, enciklika Laudato sì, ekološko obraćenje, ekološka duhounost, stvorenje

\section{UvOD}

Ekološka duhovnost je, najjednostavnije rečeno, povezivanje ekologije kao znanosti o očuvanju okoliša s duhovnošću, odnosno povezivanje duhovnosti s ekološkim aktivizmom. Sve izraženija svijest o ugroženosti Zemlje, kao zajedničkog doma, potaknula je mnoš- 
tvo osoba različitih svjetonazora i religijskih uvjerenja da se zauzmu za očuvanje okoliša te se stoga može govoriti o ekoduhovnosti različitih religija, a svjedočimo čak oživljavanju davno iščezlih poganskih kultova povezanih sa štovanjem prirode. S druge strane, s kršćanske točke gledišta, sam pojam „duhovnost“ u najširem smislu možemo shvatiti kao zauzeto življenje kršćanske vjere, što dakako uključuje vjeroispovijest, moral i bogoštovlje. Kroz povijest javljali su se i smjenjivali različiti naglasci u življenju kršćanske vjere. Ponekad je to, primjerice, u vrijeme progona, značilo povlačenje iz poganskog društva, a potom povlačenje iz društva općenito, tako da se je razvila duhovnost „bijega od svijeta - fuga mundi“, koja je stoljećima oblikovala naraštaje kršćana.

Zadnjih desetljeća suvremeni čovjek postaje sve svjesniji kako je važno čuvati okoliš, tj. svijet u kojemu živi, koji mu je darovan i kojega je i sam dio. Papa Franjo je, 24. svibnja 2015., objavio encikliku Laudato sì, odnosno encikliku o brizi za zajednički dom. Šesto poglavlje te enciklike posvećeno je ekološkom odgoju i duhovnosti te će upravo to poglavlje biti polazište našeg promišljanja o ekoduhovnosti.

\section{EKOLOŠKO OBRAĆENJE POČETAK EKOLOŠKE DUHOVNOSTI}

U početnim brojevima šestog poglavlja ${ }^{1}$ enciklike Laudato sì papa Franjo još jednom upozorava na uzroke krize suvremenog društva i čovjeka. ${ }^{2}$ Naime ističe kako je „nasilni konzumerizam primjer kako tehnološko-ekonomska paradigma utječe na pojedinca“, ${ }^{3}$ odnosno kako je suvremeni čovjek dospio u stanje da vjeruje kako je slobodan jer može slobodno kupovati i trošiti, ne primjećujući kako u biti kupuje i troši to više što mu je srce praznije. Usmjeren na sebe sama i na vlastitu kupovnu moć, postupno slabi osjećaj za opće dobro. Zato Papa i poziva na izlazak iz sebe samih prema drugima, što je preduvjet prepoznavanju drugih bića u njihovoj vrijednosti. To je ujedno temelj na kojem je moguće graditi brigu za druge i za okolišs. Kao konkretan i prvi korak u nadvladavanju individualizma - te teške bolesti od koje boluje suvremeni čovjek ${ }^{4}$ - papa Franjo

1 Usp. Papa Franjo, Laudato sì. Enciklika o brizi za zajednički dom, KS, Zagreb, 2015., 203-208. Enciklika, u prijevodu Slavka Antunovića, objavljena je kao 169 dokument u nizu: Dokumenti.

2 Cijelo treće poglavlje enciklike Laudato sì, pod naslovom: Ljudski korijeni ekološke krize, posvećeno je uzrocima ekološke krize. Usp. Laudato sì, 101-136.

3 Laudato sì, 203.

$4 \quad$ U svojoj knjizi eseja Napast nedužnosti francuski filozof Pascal Bruckner individualizam naziva bolešću suvremenog zapadnog čovjeka. Usp. Pascal Bruckner, 
ukazuje na potrebu stvaranja novih navika ${ }^{5}$ te na ekološko obraćenje. ${ }^{6}$ Pod „ekološkim obraćenjem“ Papa shvaća nov način susreta s Isusom Kristom: „Svima njima (tj. onima koji ne prepoznaju ekološku krizu, nap. M. P.) je, dakle, potrebno ekološko obraćenje, to jest da plodovi njihova susreta s Isusom Kristom izađu na vidjelo u njihovim odnosima sa svijetom koji ih okružuje. " ma, ekološko obraćenje zahtijeva nov odnos sa svijetom, kao plod na ispravan način življenog odnosa s Isusom Kristom. Papa potom ukazuje na lik sv. Franje Asiškoga kao primjer kako zdrav odnos sa stvorenim svijetom tvori jedan vid cjelovitog obraćenja. ${ }^{8}$

Istina je kako je kršćanska duhovnost tijekom stoljeća u govoru o obraćenju izgubila iz vida odnos sa stvorenjima, odnosno u prvi plan se je uvijek stavljao odnos s Bogom, a u izgradnji tog odnosa stvorenje (svijet) se je doživljavalo zapravo kao smetnju, kao nešto čega se valja osloboditi u nastojanju da se na ispravan način živi vlastiti odnos s Bogom. Papa Franjo podsjeća kako je naš poziv da „budemo čuvari Božjeg djela bitan dio krjeposnog života“. ${ }^{9}$ Drugim riječima, naš ispravan odnos s Bogom uključuje i ispravan odnos ne samo s braćom i sestrama nego i s cjelokupnim stvorenjem, koje je kao dobro proizišlo iz Božje stvarateljske ruke. Ekološko obraćenje zahtijeva i nov pogled na Boga i njegovo stvarateljsko djelo.

Poziv na obraćenje jedna je od temeljnih poruka Gospodina Isusa koji svoje poslanje započinje riječima: "Vrijeme se ispunilo, približilo se kraljevstvo Božje! Obratite se i vjerujte evanđelju!” (Mk 1,15). Predstavljajući poslanje Ivana Krstitelja, Isusova Preteče, sva trojica sinoptika kao središte njegove poruke navode njegov poziv na žurno obraćenje. U odnosu na Stari zavjet poruka Ivana Krstitelja o žurnosti obraćenja čini se radikalnom, budući da će, prema njegovu propovijedanju, propasti svi koji se pred skorašnjim dolaskom suda Gospodnjega ne obrate. Radikalizam Ivana Krstitelja, u pogledu obraćenja, još je izraženiji u poruci Isusa Krista budući da on obraćenje veže za sebe osobno. On sam postaje uosobljeno ispunjenje i prisutnost Božjeg kraljevstva. U njemu je prisutno ono obećano Jahvino spasenje kojemu se svatko treba pustiti obratiti. Ono što karakterizira sadržaj i učinke obraćenja na koje Isus poziva jesu zahtjevi koje on postavlja (usp. primjerice, Govor na gori, Mt

Napast nedužnosti, Nakladni zavod Matice hrvatske, Zagreb, 1997.

Laudato sì, 209-215.

Laudato sì, 216-221.

Laudato sì, 217.

Usp. Laudato sì, 218.

Laudato sì, 217. 
5,1-11; Lk 6,20-23). Potrebno je jednostavno napustiti sve, osobito vlastiti način na koji se misli postići spasenje te se uzdati samo u Božje milosrđe (usp. Lk 18,9-14; Mk 10,17-27). Taj zahtjev Isus izražava porukom da moramo postati poput djece (usp. Mk 10,14). Dakle, ne traži se samo kajanje za počinjene grijehe, niti samo obraćenje Bogu, nego nešto posve novo, drugačije: potrebno je učiniti se djetetom pred Božjim licem. I to je temeljni sadržaj novozavjetnog obraćenja. U tome se očituje potpuna i nova bit metanoie kako je Isus naviješta u Božje, tj. Očevo ime. On objavljuje Boga-Jahvu na posve nov način, naime kao svoga Oca (usp. Mt 11,25-30), ali i kao Oca svih ljudi koji želi primiti ljude kao svoju djecu. Spasenje koje je Bog navijestio ostvaruje se u osobi Isusa iz Nazareta. On je spasenje. Ne samo da naviješta spasenje, on ga ostvaruje u vlastitoj osobi. Stoga osobno obraćenje, koje je nužno, uključuje prihvaćanje ove besplatne ponude spasenja u Isusu u radosti darovanoga otkupljenja (usp. Mk 10,15). No, uključuje također i zahtjev da se čovjek odrekne svega ostaloga (Mk 10,28-31) te da sve procjenjuje u svjetlu ove nove stvarnosti (Mt 13,44). ${ }^{10}$

Obraćenje je, u Isusovu naučavanju, milost koja prožimlje cjelokupnu čovjekovu stvarnost. Isus omogućuje da kraljevstvo prelazi od Boga k čovjeku, kako bi čovjek, odgovarajući stavom vjere i djetinjim povjerenjem i predanjem, mogao prijeći-ući u to kraljevstvo. Jasno je da nova objava Boga, koja se je dogodila u njegovu Sinu, i događaj spasenja u istome, posvema mijenjaju i pojam 'obraćenja'. ${ }^{11}$ No, jasno je također, da obraćenje i pokora, kako ih Isus naviješta, nisu time olakšani niti su postali suvišni. Naprotiv, upravo novost objave koju donosi Isus omogućuje da se u novom svjetlu shvati dimenzija (otajstvo) čovjeka-grješnika te potreba da se čovjek odrekne svega (i samoga sebe) te da dopusti milosrdnom Bogu da ga spasi.

10 Usp. Mato Zovkić, Obraćenje i obnova Crkve kao uvjet i pratnja evangelizacije, Bogoslouska smotra, 45 (1975.) 2-3, 221-233; Nikola Roščić, Obraćenje i pomirenje, Crkva u svijetu, 13 (1978.) 4, 292-308; Anton Bozanić, Evangelizacija i obraćenje - trajni procesi, Obnovljeni život, 54 (1999.) 1, 111-115; Ivica Raguž, Kršćanska vjera i djetinji duh, Crkva u svijetu, 51 (2016.) 2, 287-301; Mladen Parlov, Obraćenje - temelj duhovne obnove, Vjesnik Đakovačke i Srijemske biskupije, CXXVI (1998.) 6, 367-371.

11 Günther Bornkamm piše kako su "spas i pokora zamijenili sada (misli na Isusovo propovijedanje, nap. M. P.) svoja mjesta. Ako je za židovsko mišljenje pokora ono prvo, pretpostavka koja grešniku daje nadu u milost, sada vrijedi da na milosti nastaje obraćenje”. Günther Bornkamm, Isus iz Nazareta, Jukić, Sarajevo, 1981., 91 . 
Evanđeoski poziv na obraćenje poziv je, s jedne strane, da se napusti vlastiti grijeh, a s druge da se postane novo stvorenje. $\mathrm{Na}$ tragu Isusova nauka prva će kršćanska zajednica razviti govor o starom čovjeku koji treba umrijeti i načiniti mjesto novom čovjeku; to djelo obnove, tj. obraćenja istodobno je djelo Božje u čovjeku i čovjekovo odgovor Bogu. ${ }^{12}$ Tijekom vremena ipak će se kršćanstvo u govoru o obraćenju dijelom vratiti na starozavjetno poimanje obraćenja koje je u prvi plan stavljalo ljudske napore (pokajanje i pokoru) u približavanju Bogu, odnosno u prvi plan dolazi moralni vid obraćenja. Postupno će tradicionalna kršćanska teologija i duhovnost (Augustin) razviti poimanje grijeha kao udaljavanje od Boga te prianjanje uz stvorenje, odnosno obraćenje će imati suprotan tijek: odvraćanje od stvorenja i obraćanje-obraćenje Bogu. Premda $\mathrm{u}$ augustinovskom poimanju kršćanskog duhovnog života posljedica grijeha nije samo udaljavanje od Boga nego i izobličenje stvorenja, ipak će se u daljnjoj kršćanskoj tradiciji razviti shvaćanje kako je stvorenje (svijet) nešto što čovjeka dovodi u napast te ga udaljuje i odvaja od Boga. To je bila podloga za razvoj monaške duhovnosti koja će obilježiti zapadno kršćanstvo sve do najnovijih vremena, a ta se duhovnost može sažeti u geslo: fuga mundi. Kršćanska se duhovnost shvaća i živi ponajprije kao nutarnji život, kao život molitve u njezinim različitim oblicima, osobito u obliku razmatranja. No novo vrijeme donosi i nove naglaske u duhovnosti, osobito zahvaljujući poticajima Drugoga vatikanskog koncila, na temelju čijih će poticaja Franjini prethodnici, Ivan Pavao II. ${ }^{13}$ i Benedikt XVI. ${ }^{14}$, progovoriti i o zaštiti okoliša, tj. o ispravnom odnosu prema stvorenjima kao dijelu kršćanskoga duhovnog života. No, ekološki su se problemi toliko usložnili da je potreban nov poticaj i nov pristup njihovu rješavanju.

12 Usp. Tullio Goffi, Conversione, u: Nuovo dizionario di spiritualità, Edizioni Paoline, Milano, ${ }^{5} 1989 .$, 291-292.

13 Sv. Ivan Pavao II. o ekološkim je temama progovorio je u više navrata: u poruci prigodom XXIII. Svjetskog dana mira (naslov poruke: Mir s Bogom Stvoriteljem, mir sa svim stvorenjem, 1. siječnja 1990.); u govoru sudionicima skupa posvećena okolišu i zdravlju, od 24. ožujka 1997.; u poruci prigodom XXXII. Svjetskog dana mira (1. siječnja 1999.); na općoj audijenciji, od 17. siječnja 2001. Više o ekologiji u misli Ivana Pavla II. vidi: Paul Haffner, L'eredità ecologica di papa Giovanni Paolo II e la bioetica, Studia Bioetica, 1 (2008.) 1, 25-31.

14 Papa Benedikt XVI. o ekološkim je temama progovorio u svojim porukama prigodom Svjetskog dana mira (2007., 2008., 2010.), potom u enciklici Caritas in veritate, br. 48-52 (2009.); u poruci prigodom proslave Dana Svete Stolice, na međunarodnom skupu u Zaragozi (10. srpnja 2008.); u govoru Rimskoj kuriji, prigodom božićnog čestitanja (22. prosinca 2008.); u homiliji održanoj na trgu sv. Petra, 2. lipnja 2006. 


\section{OD EKOLOŠKOG OBRAĆENJA DO SVIJESTI O VLASTITOJ STVORENOSTI}

Tradicionalna kršćanska duhovnost temeljila se je na pojmu grijeha i otkupljenja; najprije je čovjek sagriješio, a potom ga je Bog otkupio; kao otkupljen, čovjek je pozvan živjeti nadasve ljubav prema Bogu te potom prema bližnjemu. Dakako da je takva vizija života izgradila brojne svece i svetice. No danas, smatra papa Franjo, to više nije dovoljno. On ističe kako ekološko obraćenje u sebi uključuje niz stajališta koja trebaju ojačati duh velikodušne skrbi, ispunjene nježnošću. Konkretnije to „podrazumijeva zahvalnost i besplatnost, to jest priznanje da je svijet dar Očeve ljubavi i da smo pozvani u skrovitosti oponašati njegovu velikodušnost u požrtvovnosti i dobrim djelima... To također uključuje brižnu svijest da nismo odvojeni od ostalih stvorenja, nego da s ostalim živim bićima na svijetu tvorimo divno sveopće zajedništvo. Vjernik ne promatra svijet izvana, nego iznutra, svjestan veza kojima nas je Otac povezao sa svim bićima“. ${ }^{15}$ Papa Franjo u biti poziva da se na nov način promatra i živi vlastito biti-u-svijetu; ne više na način gospodarenja i iskorištavanja, što je bilo vlastito ljudskom ponašanju prethodnih stoljeća, a što je i dovelo do ekološke i svekolike krize u današnjem svijetu. Ekološko obraćenje treba dovesti do svijesti o vlastitoj stvorenosti, tj. o povezanosti čovjeka s cjelokupnim stvorenjem; čovjek, premda stvoren na Božju sliku i priliku, pripada svijetu stvorenja; jedino u svijetu stvorenja čovjek ostvaruje vlastiti poziv. U Božjem naumu stvaranja među stvorenjima postoji „sveopće zajedništvo“, kako veli papa Franjo. Ako je Bog Stvoritelj u sebi su-odnosnost triju božanskih Osoba tada je i stvorenje, poteklo iz njegove ruke, također su-odnosnost. Stvorenje kao skup bića postoji jer ga Bog hoće, jer je u odnosu sa svojim Stvoriteljem. Stvorenje nije drugo doli prijelaz, prelijevanje od punine bitka, koja je u Bogu, do opstojnosti pojedinih bića. Zato među stvorenjem vlada sveopće zajedništvo. U jednom Bogu Stvoritelju stvorenje je jedno! ${ }^{16}$ U stvoreni svijet Bog je, veli papa Franjo, upisao „red i dinamizam, koje ljudska bića nemaju pravo ignorirati““. ${ }^{17}$

Papin poziv da se svijet „promatra iznutra“, može se iščitati i kao poziv da se na nov način promatra Božje djelo stvaranja, odnosno Božja prisutnost u njegovim stvorenjima. Tradicionalna je teologija promatrala svijet kao dovršen; u tu dovršenost i uređenost grijeh

15 Laudato sì, 220.

16 Usp. Matthew Fox, La spiritualità del creato, manuale di mistica ribelle, Gabrielli Editori, San Pietro in Cariano, 2016., 24-25.

17 Laudato sì, 221. 
je unio nered pa se javila i potreba za otkupljenjem, tj. ponovnom uspostavom reda i sklada. No, činom stvaranja Bog se nije udaljio od svoga stvorenja; Božji stvarateljski zahvat u njegovu stvorenju je trajan; drugim riječima, stvorenje je dio Božjeg nauma spasenja; Bog je ne jednom davno stvorio svijet, nego ga uvijek iznova stvara i podržava; On trajno jest i ostaje naš Stvoritelj i Gospodin (Gospodar) svijeta i povijesti. U svijetu koji je trajno ovisan o Božjem stvarateljskom činu čovjeku pripada posebno mjesto; čovjek je ne samo stvorenje među stvorenjima nego i stvorenje kojemu je, ukoliko je obdareno razumom, povjerena briga i skrb za druga stvorenja. Tu zadaću, koju je primio od samog Stvoritelja, čovjek će ostvariti u mjeri u kojoj bude znao usvojiti i živjeti „gramatiku dara i darovanosti“, odnosno u mjeri u kojoj bude znao otkriti sakramentalnost vlastitog života i poziva da bude „između“ Stvoritelja i stvorenja. ${ }^{18}$ Pozicija čovjeka-stvorenja u stvorenom svijetu postaje upitna kad čovjek odbija biti posrednik, čuvar, kad odbija biti „između“, odnosno kad poželi sebično zavladati stvorenjem koje mu je povjereno. Tada se remeti red i sklad koje Bog upisuje u svoja stvorenja. Papa Franjo veli kako Zemlja, naša sestra i majka, ,jeca zbog zla koje joj nanosimo, zbog neodgovornog korištenja i zloporabe dobara koje je Bog stavio u nju. Odrasli smo misleći da smo njezini vlasnici i gospodari, kojima je dopušteno pljačkati je do mile volje. Nasilje koje prebiva u ljudskom srcu, ranjenom grijehom, očituje se također u znakovima bolesti koje primjećujemo u tlu, vodi, zraku i živim bićima“. ${ }^{19}$ Ljudsko srce, grijehom ranjeno, dovelo je do oblikovanja pogrješnog shvaćanja čovjeka i njegove uloge u svijetu u kojemu živi i kojemu pripada.

S prosvjetiteljstvom je započeo proces u kojem je čovjek sebe postavio kao mjeru svega; u središtu svega nalazi se čovjek pozvan sebe ne samo ostvarivati nego se i samostvarati; svijet i stvorenje $u$ svijetu služe čovjeku u njegovo obogotvorenju, u njegovo pokušaju da zauzme mjesto Boga. Taj izobličeni antropocentrizam je posijao sjeme koje se je razvilo u golemo stablo koje rađa gorkim plodovima. Prvi plod tog stabla je suvišnost Boga i njegova djelovanja u svijetu. U svijetu u čijem se središtu nalazi mali bog - čovjek, istinski je Bog potjeran na nebo, gore; nama je dovoljna priroda i ono što nam

18 Usp. Massimo Losito, L'ecologia umana al cuore dell'ecologia integrale nel magistero di Papa Francesco, Studia Bioetica, 9 (2016.) 2, 54-57; Francesco Botturi, Laudato sì, unita e relazione. Prospettiva antropologica, u: Claudio Giuliodori Pierluigi Malavasi (ur.), Ecologia integrale. Laudato sì. Ricerca, formazione, conversione, Vita e Pensiero, Milano 2016., 23-29.

Laudato sì, 2. 
nudi, a sve što u sebi nosi ponuđeno je čovjeku za njegovo obogotvorenje i njegov užitak. U svijetu bez Boga i vječnih zakona najvažnija je korist, a posljedično i umijeća koja omogućuju korist. Dakako da u takvoj viziji čovjeka i svijeta stradava Zemlja-svijet, ali i sam čovjek postaje žrtva svoga bezumlja. ${ }^{20}$

Nasuprot izobličenom antropocentrizmu kršćanstvo ispovijeda vjeru u Boga - stvoritelja neba i zemlje, svega vidljivoga i nevidljivoga; što dakako uključuje i stvaranje čovjeka koji je, kako uči Katolička Crkva, ,jedino stvorenje što ga je radi njega samoga Bog htio, on je jedini pozvan da spoznajom i ljubavlju dijeli Božji život“. ${ }^{21}$ Crkva također uči „kako je Bog sve stvorio za čovjeka, a čovjek je stvoren da služi Bogu, da ga ljubi i da mu sve stvorenje prikazuje“. ${ }^{22}$ Čovjek, stvoren na Božju sliku i priliku, pozvan je u ime Božje upravljati Božjim stvorenjem, na način da u konačnici to isto stvorenje Bogu prikazuje. To će biti moguće jedino kroz ponovno otkriće vlastite stvorenosti, vlastite pripadnosti stvorenom svijetu i ponovno otkriće odgovornosti za stvorenje koje Bog Stvoritelj povjerava čovjeku, kojega poziva da bude su-stvaratelj svijeta koji mu je povjeren. U Božjem stvarateljskom naumu čovjek, premda po dostojanstvu neizmjerno nadilazi stvoreni svijet, ipak ostaje dio stvorenja. Kao primjer - uzor odnosa prema stvorenju papa Franjo stavlja nam pred oči lik sv. Franje Asiškoga čije nam „svjedočanstvo pokazuje da cjelovita ekologija iziskuje otvorenost prema kategorijama koje nadilaze jezik egzaktnih znanosti ili biologije i dovode nas do same čovjekove biti“. ${ }^{23}$

Ako čovjek ne uspostavi ispravan odnos prema stvorenjima, tj. ako ih poželi iskorištavati za svoje sebične interese, tada remeti onaj red i sklad koji je Stvoritelj upisao u svoja stvorenja; tada griješi. Grijeh protiv Božjeg stvorenja istodobno je grijeh protiv samoga Stvoritelja. Stoga papa Franjo ističe kako je u procesu ekološkog obraćenja potrebno razvijati svijest „da svaki stvor odražava nešto Božje i ima poruku koju nam želi prenijeti, odnosno sigurnost da

20 U drugom dijelu enciklike, pod naslovom Evanđelje stvaranja, papa Franjo upozorava: „Duhovnost koja zaboravlja svemoćnog Boga i Stvoritelja nama je neprihvatljiva. To na kraju dovodi do toga da se čovjek klanja silama ovoga svijeta i prisvaja mjesto koje pripada Bogu, tvrdeći da ima neograničeno pravo gaziti stvarnost koju je Bog stvorio. Najbolji način da se čovjeka vrati na njegovo pravo mjesto, okončavajući njegovu umišljenost da je apsolutni vladar zemlje, jest ponovno predstaviti sliku Oca stvoritelja i jedinog gospodara svijeta, jer će u protivnom čovjek uvijek težiti tome da stvarnosti nameće vlastite zakone i vlastite interese."Laudato sì, 75.

21 Katekizam Katoličke Crkve, HBK - Glas Koncila, Zagreb, 1994., 356.

22 KKC, 358.

23 Laudato sì, 11. 
je Krist preuzeo u sebe taj materijalni svijet i sada, kao uskrsnuli, prebiva u dubinama svakog bića, okružujući ga svojom ljubavlju i prožimajući ga svojim svjetlom“. ${ }^{24}$ Krist, koji „prebiva u dubinama svakog bića“, nalazi se u središtu, u srcu svega stvorenoga. Ova misao priziva sadržaj velebnog himna iz poslanice Kološanima prema kojem je Krist „slika Boga nevidljivoga, Prvorođenac svakog stvorenja. Ta u njemu je sve stvoreno na nebesima i na zemlji, vidljivo i nevidljivo... sve je po njemu i za njega stvoreno: on je prije svega i sve stoji u njemu“ (Kol 1,15-17). Taj je himan pozivao prve kršćane da se oslobode straha pred fatumom-sudbinom, u kojoj vladaju „konstelacije zvijezda“ ili „sudba slijepa“. Za kršćane svijet je proistekao iz Božje ruke, a u njegovu središtu, kao njegov Izvor i Svrha, nalazi se Isus Krist po kojemu je Bog izmirio sa sobom sve, na nebesima i na zemlji (usp. Kol 1,20).

Ekološko obraćenje, kao početak ispravne kršćanske duhovnosti, treba prožeti svakog kršćanina kojemu je, na razini na kojoj jest, povjerena briga o dijelu stvorenog svijeta. No to, smatra papa Franjo, nije dovoljno: u skrbi za zajednički dom, za svijet u kojem živimo, potrebno je obraćenje zajednice. ${ }^{25}$ Ono će se postići, nastavlja Papa, bude li zajednica ispunjena stavovima zahvalnosti i besplatnosti, odnosno ako u njoj sazrije svijest kako joj je svijet darovan kao besplatan dar Očeve ljubavi te kako je i sama i svaki pojedinac u njoj pozvan oponašati velikodušnost Oca nebeskog.

\section{UlOGA SAKRAMENATA U EKOLOŠKOJ DUHOVNOSTI}

Bog se je u Isusu Kristu „materijalizirao“, postao je vidljiv i opipljiv, postao je dio svijeta koji je stvorio. Čovjek je cilj Božjeg djelovanja, premda ne isključivi. U svome približavanju čovjeku Bog se služi jezikom koji je čovjeku razumljiv, a pritom ne mislimo samo na ljudski govor nego i na tjelesno-materijalnu dimenziju ljudskog doživljaja i shvaćanja svijeta. U ekonomiji spasenja Bog želi da spasenje bude posredovano, ne samo na način da Crkva - Posrednica - nastavlja djelo jedinog Posrednika, Isusa Krista, nego sam Bog ustanovljuje određene vidljive znakove (sakramente) po kojima nam priopćava nadnaravne darove, milosti. Papa Franjo veli kako su

24 Laudato sì, 221. Opširnije o čovjekovoj odgovornosti za stvoreni svijet, odnosno o cjelovitoj ekologiji, kako je naziva papa Franjo, vidi: Franco Anelli, La natura come creazione e le responsabilità dell'uomo, u: Claudio Giuliodori - Pierluigi Malavasi (ur.), Ecologia integrale. Laudato sì. Ricerca, formazione, conversione, 3-10. 
„sakramenti povlašteni način na koji priroda biva preuzeta od Boga i pretvorena u sredstvo posredovanja nadnaravnog života... Kada želimo susresti Boga, mi ne bježimo od ovog svijeta i ne okrećemo leđa prirodi... za kršćansko iskustvo sva stvorenja materijalnog svijeta nalaze svoj pravi smisao u utjelovljenoj Riječi, jer je Sin Božji u svojoj osobi utjelovio dio materijalnog svijeta i u njega zasadio sjeme konačne preobrazbe“. ${ }^{26}$

Svi sakramenti, kao vidljivi znakovi koji nam omogućuju pristup u otajstvo Isusa Krista, dio su stvorenog svijeta po kojima se Bog - Stvoritelj približava i dariva čovjeku. To posebno vrijedi za sakrament Euharistije, u kojoj je „stvorenje uzdignuto na najvišu razinu... /Euharistija/ je živo središte svemira, vrelo iz kojega se u preobilju izlijevaju ljubav i nepresušan život" ${ }^{27}$ Milost, kao Božji pokret prema čovjeku i jer se nudi čovjeku ukoliko je duhovnotjelesno biće, teži očitovati se u opipljivu obliku. Najviši izričaj tog Božjeg izlaženja i prilaženja čovjeku dogodio se je u utjelovljenju Sina Božjega. Ali tu nije stalo. Bog ide korak dalje i dublje: On se želi darovati čovjeku kao hrana, kao jelo koje će čovjeku darovati ono što je vlastito samo Bogu: život vječni. Euharistija je krajnja posljedica Utjelovljenja, ukoliko i jedno i drugo otajstvo imaju za cilj čovjekovo preobraženje i pobožanstvenjenje. U ostvarenju tog nauma svoga milosrđa Bog se služi materijom (kruhom i vinom) koju je sam stvorio, ali i koja je ujedno oblikovana djelom ljudskih ruku. U Euharistiji, koja uprisutnjuje sva otajstva Krista raspetog i uskrsnulog, materija je dodirnula svoje ispunjenje, svoju konačnost, koja se sada, kao konačna i sveobuhvaćajuća, nudi čovjeku. Istodobno u Euharistiji, u jedinstvu s utjelovljenim Sinom Božjim, sav svemir uzdiže hvalu Bogu. Zato je Euharistija čin kozmičke ljubavi, papa Franjo navodi misao sv. Ivana Pavla II. ${ }^{28}$ Euharistija, kao čin Božjeg sebedarja svome stvorenju, združuje nebo i zemlju, obuhvaća i prožima sve stvoreno. U otajstvu Euharistije svijet, koji je proizišao iz Božje ruke kao dobar, vraća se svome Stvoritelju u radosnom i savršenom klanjanju. I ne samo to, nego je u Euharistiji stvoreni svijet protegnut prema svome pobožanstvenjenju, prema svetoj gozbi, prema ujedinjenju sa samim Bogom. ${ }^{29}$

26 Laudato sì, 235.

27 Laudato sì, 236.

28 Papa Franjo navodi misao Ivana Pavla II., iz enciklike Ecclesia de Eucharistia, 8: „Da, kozmički! Jer i kada se slavi na malom oltaru koje seoske crkve, euharistija se uvijek slavi, u određenom smislu, na oltaru svijeta." Laudato sì, 236.

29 Navedene misli papa Franjo preuzima iz propovijedi pape Benedikta XVI., održane na svetkovinu Tijelova, 15. lipnja 2006. Usp. Laudato sì, 236. 
Slavlje Euharistije ne može se odijeliti od nedjelje kao dana Gospodnjega koji je, u Božjem naumu, zamišljen kao dan ozdravljenja čovjekovih odnosa s Bogom, sa samim sobom, s drugima i sa svijetom. ${ }^{30}$ Svojim uskrsnućem od mrtvih Gospodin Isus je postavio temelj novog stvaranja, novog stvorenja, novog čovječanstva te je ujedno postavo zalog konačne preobrazbe stvorenog svijeta. U uskrslom tijelu našega Spasitelja materija je došla do svoga ispunjenja. U nedjelju se naviješta čovjekov vječni počinak u Bogu te se upravo po nedjelji sjedinjuje vrijeme odmora i slavlja. Nedjelja, kao dan počinka, omogućuje čovjeku da uzdigne pogled sa svakodnevne, često turobne stvarnosti, prema nebeskim visinama, odnosno omogućuje mu da svome tjednom radu dade smisao koji mu često izmiče.

\section{ODGOJ ZA EKOLOŠKU DUHOVNOST}

Kršćanska je duhovnost po sebi pokušaj da se ljudski život shvati, prihvati i živi iz drugačije perspektive nego je nudi suvremeni svijet. Kršćanska duhovnost nudi vjerniku proročki i kontemplativan pogled na život i način življenja; na život u kojemu prvenstvo ne će imati potrošnja i gomilanje materijalnih dobara, nego kvaliteta života koja shvaća kako je često u životu „manje u biti više“. ${ }^{31}$ To istodobno znači svjesni izbor života u umjerenosti i razvijanju svijesti kako se vrijednost života ne mjeri količinama svari koje čovjek posjeduje, nego bogatstvom i ljepotom odnosa koje uspostavlja s drugima osobama. Spomenuta umjerenost potrebna je suvremenom čovjeku poput kruha nasušnoga, jer se čini kao da suvremeni čovjek nema drugog izbora doli šopinga i seksa. Umjerenost vodi do veće slobode pod dva vida: slobode od navezanosti na suvišne i često posve nepotrebne stvari, koje se grozničavo kupuju i gomilaju, a drugo vodi do oslobađajućeg pogleda prema drugima, tj. do prepoznavanja potreba drugih osoba. Posljedica takvih izbora jest smanjenje tjeskobe i umora koji se javljaju jer se ne ispunjanju pretpostavljena očekivanja drugih osoba. Papa Franjo upozorava kako gubitak poniznosti, koja je povezana s umjerenošću, dovodi „do nanošenja štete društvu i okolišu“. ${ }^{32}$

\footnotetext{
$30 \quad$ Usp. Laudato sì, 237.

31 Papa veli kako je uvjerenje „manje je više“ prisutno u različitim religijskim tradicijama te u Bibliji, odnosno kako i danas valja razvijati sposobnost da se bude zadovoljno i s malim. Usp. Laudato sì, 222.

32 Laudato sì, 224
} 
Papa Franjo također upozorava kako je važan vid kršćanskog duhovnog života nutarnji mir, koji je usko povezan s brigom za okoliš i opće dobro. Naime, „cjelovita ekologija zahtijeva da odvojimo vrijeme kako bismo vratili vedar sklad sa stvorenim svijetom, razmišljali o našem načinu života i našim idealima, uronili u kontemplaciju Stvoritelja koji živi međi nama i u onom što nas okružuje, i čija 'se prisutnost ne smije neprirodno stvarati, već treba biti otkrivena i pronađena'“. ${ }^{33}$ Papa nudi i konkretan savjet kako razvijati potrebnu umjerenost, poniznost i zahvalnost za darovana stvorenja. Veli kako je važno znati zahvaliti Bogu prije i poslije jela, jer nas taj trenutak zahvale podsjeća kako naš život ovisi o Bogu, jača naš osjećaj zahvalnosti za darove stvaranja te izražava našu zahvalnost prema onima koji su nam svojim trudom priskrbili dobra koja uživamo. ${ }^{34}$

\section{NEKI NAGLASCI EKOLOŠKE DUHOVNOSTI}

Kršćanska duhovnost po sebi je hod za Isusom Kristom, odnosno prihvaćanje dara novog života koji Otac nebeski nudi u svome Sinu, a koji nam se priopćava u Duhu Svetomu. Iz te darovane novosti rađa se „novi čovjek“, koji će po uzoru na Isusa Krista nastojati uspostaviti ispravne odnose $\mathrm{s}$ Bogom, sobom, drugima i svijetom $\mathrm{u}$ kojem živi. Kad je riječ o odnosu prema svijetu u kojem živi, odnosno prema svemu stvorenom, kršćanin bi trebao izbjeći dvije krajnosti: gnosticizma i panteizma. Napast gnosticizma vodi kršćane u prijezir i odbacivanje stvorenog, materijalnog svijeta kao zloga, kao nečega što sprječava i onemogućuje duhovni život. Ovakav stav prema stvorenju računa samo na čovjekovu duhovnu sferu, a zaboravlja kako je čovjek i tijelo te kako se je Bog utjelovio, tj. kako je i sam postao dio stvorenog svijeta. Druga krajnost jest panteizam, odnosno obožavanje prirode, stvorenja kao božanskog. Ovakav stav obožavanja stvorenog svijeta kao božanskog, a koji je prisutan kod brojnih ekoloških aktivista, lako preraste u mržnju prema čovjeku koji uništava Majku Prirodu.

Na temelju Objave, ali i zdravog razuma kršćanin zna kako je svijet dobar jer je potekao iz ruke dobrog Boga Stvoritelja te kako odnos s Bogom Stvoriteljem uključuje ispravan odnos i s njegovim stvorenjem. Ili, bolje reći, ispravan odnos s Bogom Stvoriteljem jamči i dobar odnos s cjelokupnim stvorenjem. To bi u življenju ekološke

33 Laudato sì, 225.

$34 \quad$ Usp. Laudato sì, 227. 
duhovnosti uključivalo izgradnju novih stavova i životnih navika. ${ }^{35}$ Evo nekih:

1. Pred ljepotom, raznolikošću i mnoštvom stvorenja u nama se trebaju spontano javiti osjećaji zahvalnosti i divljenja jer je sve stvorenje Stvoritelj u svojoj mudrosti stvorio poradi čovjeka. Stvoritelj svoje stvorenje povjerava čovjeku da njime odgovorno upravlja, odnosno Bog želi čovjeka kao sustvaratelja ovog svijeta. ${ }^{36}$ Čovjekova je zadaća da stvoreni svijet „obrađuje i čuva“ (Post 2,15). Bog stvara ovaj svijet svojom riječju, što nas vodi do zaključka kako je svako stvorenje „riječ Božja“ te kako u svakom od stvorenja odsijeva Božja stvarateljska mudrost. Činjenica da Bog svoje stvorenje povjerava $u$ naše ruke treba nas ispuniti dubokom zahvalnošću, ali i dubokim poštivanjem Božjeg djela. To posebno vrijedi za poštivanje svih oblika života, a u Božjem svijetu sve je živo, jer od Boga-Života sve prima vlastitu opstojnost, vlastiti život, od kukaca do biljaka.

2. Ne smijemo zaboraviti da smo dio ne samo stvorenoga nego i paloga svijeta, tj. da smo u svojoj nutrini duboko ranjeni te da $\mathrm{u}$ svojoj ranjenosti, kao posljedici istočnoga grijeha, lako poželimo biti gospodari umjesto čuvari stvorenog svijeta. Ljudsko srce ne želi i ne može biti prazno. Ako nije ispunjeno onim što ga jedino doista može ispuniti, tj. Bogom, ono se puni stvorenjem, ali na način da što se više puni to više ostaje prazno. Kršćanin ne bi nikada smio zaboraviti kako se veličina i ljepota ljudskog života ne krije u nagomilavanju stvari, često suvišnih i nepotrebnih, nego u ljepoti odnosa s drugima, osobama i svijetom u kojem živimo. A preduvjet ispravnosti tih odnosa jest ispravan odnos s Bogom. Naime, jedino srce ispunjeno prisutnošću živoga i osobnog Boga može druge susretati na način da im poželi služiti, a ne iskorištavati ih. Odnos s Bogom gradi se ponajprije molitvom, odnosno našim nastojanjem da spoznamo i izvršimo volju Božju, jer je to temeljni kriterij naše bliskosti

35 U članku posvećenu ekološkoj duhovnosti u svjetlu enciklike Laudato sì, Ivan Platovnjak nabraja sljedeće stavove: 1) stav zahvalnosti i besplatnosti; 2) stav uzajamnog življenja te poštovanja prema okolišu, ljubavi i solidarnosti; 3) svijest o zajedničkom domu i zauzetost za opće dobro; 4) stav umjerenosti, radosti i mira; 5) stav sakramentalnog života; 6) stav nedjeljnog odmora i slavlja; 7) kontemplativni stil življenja. Usp. Ivan Platovnjak, The Ecological Spirituality in the Light of Laudato si, Nova prisutnost, 17 (2019.) 1, 82-85.

36 Drugi izvještaj o stvaranju predstavlja čovjeka kao Božjeg suradnika u djelu stvaranja: „Jahve, Bog uzme čovjeka i postavi ga u edenski vrt da ga obrađuje i čuva... Tada Jahve, Bog, načini od zemlje sve životinje u polju i sve ptice u zraku i prevede ih čovjeku da vidi kako će koju nazvati, pa kako koje stvorenje čovjek prozove, da mu tako bude ime. Čovjek nadjene imena svoj stoci, svim pticama u zraku i svim životinjama u polju“ (Post 2,15.19-20). U biblijskom poimanju nekome ili nečemu dati ime znači imati vlast nad onim kome se ili čemu se dalo ime. 
s Isusom Kristom, odnosno preduvjet našega hoda za njim. To nas vodi do zaključka kako je i u ekološkoj duhovnosti briga oko vlastite molitve najvažnija od svih zadaća svakog kršćanina. Svakodnevna ozbiljna i organizirana molitva brzo će dovesti do slobode od strahova koje razdiru suvremenog čovjeka i koji ga sile da na krivi način živi vlastito poslanje. No kako se ne bi dogodilo, a lako se dogodi, da se čovjek moli Bogu kojega je „stvorio na vlastitu sliku“, trebat će osobnu molitvu usmjeriti prema molitvi koju sam Bog traži od svoje djece, naime prema molitvi Crkve, odnosno prema Euharistiji. Osobna molitva pomoći će liturgijskoj molitvi da se ne pretvori u formalizam, u besplodno poštivanje propisa, a liturgijska molitva pomoći će osobnoj molitvi da ne „zaluta“, da ne skrene na krive putove, bilo u spiritualizam, bilo u razne vrste sektaštva.

3. U ekološkoj duhovnosti prevažno mjesto mora zauzimati askeza, odnosno odricanje od suvišnoga i nepotrebnoga, ili, kako bi papa Franjo rekao, oblikovanje životnog stava kako „manje znači više“. Riječ je zapravo o tome da se vlastito srce drži slobodnim, a to u stanju naše pale naravi nije moguće bez odricanja, bez askeze. Potrebno je iznova naučiti, primjerice, ciljano kupovati, i to samo ono što je zaista potrebno; kuhati samo onoliko koliko je potrebno; odreći se ne samo onoga što bi vodilo do nedopuštenog užitka, tj. do grijeha, nego i onoga što je dopušteno. Ako u motivaciji za odricanjem nisu dostatni duhovni razlozi (suobličenje Kristu patniku; zadovoljština za grijehe i sl.), trebali bi biti barem zdravstveni. Naime, hrana koju konzumiramo uglavnom je obrađena na razne načine te u sebi sadrži brojne sastojke koji mogu biti štetni za naše zdravlje. Zato je dobro što češće postiti kako bi se naše tijelo oslobodilo štetnih sastojaka koje hranom unosimo u svoje tijelo. A naše je tijelo hram Boga živoga (usp. 1 Kor 3,16 ). Danas nam je poput kruha nasušnoga potrebna osobito „askeza očiju“, jer preko osjetila vida $u$ našu nutrinu ulazi mnoštvo suvišnih slika i informacija, često štetnih i razarajućih, koje iskrivljuju naš pogled na svijet, a posljedično i naš odnos prema drugima i svijetu u kojem živimo.

4. Odricanje i askeza mogu nam pomoći do stjecanja veće slobode koju nam Krist nudi (usp. Gal 5,1). No, odricanje nije cilj duhovnog života; ono je samo sredstvo na putu sve većeg suobličenja Isusu Kristu, na putu do života u slobodi djece Božje. Suobličenja Kristu nema bez ljubavi prema bližnjima, prema onima koje nam Providnost stavlja na naš životni put. To nas pak vodi do zaključka kako je za ispravan duhovni život nužna solidarnost s drugima. Ekološka duhovnost uključuje solidarnost ne samo s ljudima, kao drugima i bližnjima, nego i sa svim drugim stvorenjem. Konkretno to znači 
aktivno sudjelovanje u programima i planovima koji teže za poboljšanjem međuljudskih odnosa, ali i za očuvanjem prirode. Kršćaninu ne može biti svejedno kakva se politika provodi u društvu u kojem živi; kakva je kultura, obrazovanje, briga oko općeg dobra itd. Živjeti ekološku duhovnost ne znači samo znati kritizirati nego se i aktivno zauzeti da se svijet učini boljim i ljepšim mjestom za življenje jer je to volja Onoga koji je svijet stvorio, a svakog čovjeka, posebno svakog kršćanina, poziva da postane sustvaratelj svijeta u kojem živi.

\section{ZAKLJUČAK}

Ekološka duhovnost zahtijeva prije svega promijenjen odnos prema svemu što nas okružuje. Ispravan ekološki stav dovest će do nutarnje ravnoteže u samom čovjeku, do solidarne ravnoteže s drugima, do prirodne ravnoteže sa svim živim bićima te do duhovne ravnoteže s Bogom. Ekološka svijest može pomoći ne samo očuvanju okoliša, što se nameće kao jedan od temeljnih ciljeva, nego i dovesti do promjene ponašanja koja može podići kvalitetu življenja, kako pojedinca tako i obitelji. Primjerice, ako izbjegavamo u trgovini kupovati ono što nam ne treba, manje će biti otpada u našim obiteljima; potom, ako kuhamo hrane onoliko koliko nam treba, također će biti manje otpada i smeća; ako se potrudimo razvrstati smeće, a osobito ga ne odlagati tamo gdje mu nije mjesto, naš će život i okoliš postati ljepši i zdraviji. To nas, dalje, mora potaknuti da se ustrajno borimo protiv napasti konzumerizma, tj. kupovanja suvišnih stvari samo zato što su nove, jer se reklamiraju, jer ih ima netko drugi, jer su u modi itd. Valja nam također naučiti odbaciti i utilitaristički pragmatizam po kojemu se ponašamo kao iskorištavači svega, od kamena, do drva i zemlje. Valja nam se naučiti diviti ljepoti prirode, stvorenja, ljepoti svega što živi i što se miče, od živih bića do lišća. Doista, svima nam je potrebno ekološko obraćenje, odnosno da se iz našeg vjere i susreta s Isusom Kristom počne mijenjati i naš odnos prema svijetu koji nas okružuje, jer je Krist po svome utjelovljenu i uskrsnuću preobrazio cjelokupno stvorenje. Ispravan odnos prema okolišu polazi od svijesti da smo i mi ljudi dio stvorenoga svijeta, svijeta koji nam je darovao dobri Stvoritelj da na njemu i od njega živimo, ali ne i da ga uništavamo. Kao dio stvorenoga svijeta pozvani smo poštivati sve oblike života, tj. sva živa bića. Svako od njih ima svoju svrhu i ulogu koju mu je namijenio Stvoritelj svega. Ako neka od njih nanose štetu (štetočine) nama ili djelu naših ruku, naravno da se možemo i moramo od toga obraniti, ali s razboritošću i oprezom, da ne izazovemo veće zlo za sebe i svoje, bilo na duge ili kraće staze. 


\section{THE DRAFT OF ECO-SPIRITUALITY ACCORDING TO POPE FRANCIS' ENCYCLICAL LAUDATO Sİ}

\section{Summary}

In the wake of the Pope Francis' encyclical Laudato sì which talks about the Earth as a common home of all people, the author offers a draft of ecological spirituality. The beginning of true eco-spirituality is ecological conversion, which is nothing else but a renewed consciousness that from our faith and encounter with Jesus Christ we also ought to change our relationship with the world around us. Ecological conversion should help the faithful to repeatedly and correctly develop their awareness of having been created, of their own immersion into the world of creatures with which they are interconnected. Correct ecological attitude leads to internal balance of the man himself, to solidarity with others, to natural balance of all living beings and to spiritual balance with God. Ecological awareness can help not only to preserve the environment, which is one of the basic goals, but also to change the way of behaviour, which can raise the quality of life of both the individual and the family. Ecological spirituality understands and lives the sacraments in a new way, as a means of salvation and sanctification, because in the sacraments God uses the visible matter in order to communicate his (invisible) grace. Eco-spirituality calls for upbringing and adopting new attitudes in the lives of contemporary Christians which need to help them to properly treat the created world.

Key words: Pope Francis, encyclical Laudato sì, ecological conversion, eco-spirituality, creature 